\title{
HERVORMING ONZER STAATSBEGROOTING. ${ }^{1}$ )
}

II.

Het baseeren van een rationeele financieele politiek op de verdeeling der uitgaven in productieve en onproductieve in den, bij de bespreking der Staatsfinancien gebruikelijken, zin bleek ons de vorige maal noch de praktijk van particulieren, gemeentebesturen en provinciale besturen, noch ook theoretisch verdedigbaar.

Het wil mij voorkomen, dat voor de verdeeling der lasten over heden en toekomst geen ander beginsel mag gelden en behoeft te worden in acht genomen dan, dat wie de lusten heeft ook de lasten moet dragen.

Ligt het voorzeker niet op den weg van den Staat om het kapitaal, dat door de individuen wordt gevormd, te doen verminderen, mag hij dus niet om de ingezetenen diensten te bewijzen, welke deze uit hun gewone inkomsten behooren te betalen, het in den loop der tijden gevormde staatsvermogen opteren, mag hij ook niet als betaling van de diensten belasting vorderen, welke hij moet veronderstellen dat door de contribuabelen uit hun kapitaal worden voldaan in plaats van uit hun inkomen, mag hij eindelijk ook njet zulke diensten verschaffen uit gelden, die zijn geleend, hetzij bij een deel der ingezetenen, hetzij elders, anderzijds ligt ook kapitaalv orming ${ }^{2}$ niet op den weg van den Staat.

1) Ik mag niet nalaten aan te teekenen, dat ik op bladz. 82 van het $I^{\theta}$ gedeelte geheel ten onrechte schreef, dat het standpunt, dat wat aan den Staat wordt betaald economisch gesproken verloren rijkdom is, in Boissevain's brochure werd ingenomen. Een onjuist begrepen aanteekening indertijd uit die brochure gemaakt deed mij als B's opinie geven wat door hem als een nog veel verbreide meening wordt aangehaald en bestreden.

2) Tenzij dan een reserve voor een bepaald aangewezen doel. Econ. 1912. 
Aan de individuen moet worden overgelaten, in hoeverre zij wenschelijk achten voor hun nageslacht (of het nageslacht) kapitaal te vormen. Het is natuurlijk in het belang der maatschappij, dat de Staat spaarzin, gevoel van verantwoordelijkheid voor de toekornst aankweekt, maar gansch iets anders is het door dwang kapitaal te vormen en dan nog niet eens ten behoeve van den gedwongene zelf of van diens nageslacht doch ten behoeve van het nageslacht (de toekomstige contribuabelen).

De belastingschuldigen van de toekomst kunnen tevreden zijn, als zij geen lasten hebben te dragen waar geen lusten tegenoverstaan m. a. w. geen lasten voor de lusten van het verleden, en als er overigens in het verleden gedaan is wat mogelijk was voor de intellectueele, moreele en materieele verheffing van de natie, zoodat de draagkracht is toegenomen.

In de praktijk wijkt intusschen de naleving van het beginsel, dat wie de lusten heeft ook de lasten moet dragen, volstrekt niet vér af van hetgeen er thans bij ons geschiedt.

Schijnbaar passen wij het beginsel thans alleen toe : eenerzijds voorzoover wij rente en aflossing betalen van hetgeen vroeger geleend is om den Staat een groot complex van gebouwen en inrichtingen ten publieken dienste te doen verkrijgen en anderzijds voorzoover wij zelf leeningen aangaan voor zaken van langdurig nut en dus de toekomst met rente en aflossing belasten. Voor zoover wij profiteeren van de diensten van werken en inrichtingen, welke vroeger uit de gewone inkomsten zijn betaald en op onze beurt werken en inrichtingen van langdurig nut uit onze gewone inkomsten betalen, lijkt het alsof wij noch betalen voor alle lusten, die wij hebben, noch ons beperken tot het dragen van de lasten, welke wij in billijkheid behoeven te dragen.

Intusschen hetgeen wij aan de toekomst als het ware gratis leveren is te beschouwen als de vorm, waarin wij betalen voor de diensten van hetgeen onze voorgangers ons gratis leverden. Voor de diensten, welke wij genieten betalen wij. uit ons inkomen in voldoende mate, wanneer wij het staatsvermogen, gelijk wij het aantroffen, op peil houden. Alle bezittingen van den Staat, alleen de grond in de meeste 
gevallen uitgezonderd, dalen elk jaar in waarde, hetzij alleen door slijtage, hetzij door slijtage en ongeschikt worden voor hare bestemming beiden. Tegenover dien achteruitgang van het staatsvermogen, moet eene gelijke vorming van vermogen staan, willen wij ons niet schuldig maken aan interen, aan kapitaalvernietiging. Dit vormen van staatsvermogen kunnen wij zoowel doen door uit den weg ruimen van negatief staatsvermogen (staatsschuld) als door het toevoegen van nieuwe vermogensbestanddeelen uit onze gewone inkomsten.

Ten onzent wordt er langs beide wegen naar gestreefd het staatsvermogen op peil te houden en dus de lasten te dragen, welke wij in verband met de diensten van het staatsvermogen behooren te dragen.

Vooreerst betalen wij de rente en de aflossing der leeningen, en voorts wordt er telken jare een belangrijk bedrag ten laste van den gewonen dienst gebracht voor de totstandbrenging van werken, waaraan de contribuabelen van het betrokken belastingjaar weinig of niet genieten doch slechts de toekomst genot zal hebben.

Intusschen is dit gecombineerde systeem allerminst geschikt om zoo nauwkeurig mogelijk te bereiken wat men wil.

Elk der beide wijzen, waarop wij het tegenwoordige geslacht laten betalen voor het genot van de diensten van vroeger gestichte werken, is een uiterst gebrekkige poging om de contribuabelen van het betrokken jaar behoorlijk, d. i. niet te veel en niet te weinig, te laten betalen.

Voor zooveel de amortisatie van schuld betreft, is dit het gevolg van de wijze, waarop bij ons de werkelijke dekking van de uitgaven, waarvoor men aanneemt, dat wel geleend mag worden, pleegt te worden geregeld.

Ik zeg de werkelijke dekking. Men stelt meestal tegenover elkaar dekking door leening en dekking door gewone inkomsten. Het behoeft na al het voorafgaande wel geen betoog, dat de tegenstelling niet zuiver is. Zijne uitgaven dekken door leening kan op den duur niemand - ook een Staat niet. Dekking door leening is altijd slechts een tijdelijke dekking; er moet ten slotte ter zake van elkwerk, dat de Staat aanvankelijk niet uit gewone midde'en betaalt, een bedrag ten: laste van de gewone inkomsten worden 
gebracht, wil het niet op den duur op een staatsbankroet uitloopen.

De sommen voor aflossing ${ }^{1}$ ) van de leening aan de gewone middelen van volgende jaren onttrokken, zijn de feitelijke dekking van de uitgave, die tijdelijk door het opnemen van geld mogelijk werd gemaakt. Had men zulks ten allen tijde ingezien, dan zoude er in zake Staatsleeningen vermoedelijk anders gehandeld zijn dan in werkelijkheid het geval was. Als men leende, werd er bij den Staat in den regel zeer weinig rekening gehouden met het belangrijke punt: waarvoor men leende.

„Een Staatsleening sluiten", zoo werd betoogd, ,is „niets „anders dan een kaskwestie". „De vlottende schuld (dat „zijn de leeninkjes telkens voor zeer korten tijd gesloten) "loopt te sterk op; de Staat legt te zeer beslag op het „,vlottende kapitaal van de geldmarkt; hij schaadt dienten"gevolge handel en nijverheid en moet wat hij'van dat „vlottende kapitaal heeft, aan de geldmarkt teruggeven, „,door een beroep te doen op het kapitaal voor blijvende ,beleggingen beschikbaar. Het is dus eenvoudig een om,zetting. De voorwaarden van de leening moeten alleen „afhangen van de vraag: op welke conditiën komt de Staat ,het goedkoopst aan geld, welke aflossingstermijn ziet de "geldmarkt het liefste en welke amortisatie kan de be"grooting, gegeven den stand der geldmiddelen dragen". 2) Waarvoor er geleend werd en wat in verband daarmede de aflossingstermijn behoorde te zijn, legde bij deze opvatting gewoonlijk al zeer weinig gewicht in den schaal. En erkend moet worden, dat het ook meestal bezwaarlijk was daarmede nauwkeurig rekening te houden. De vlottende

1) Feitelijk ook van de rente, die immers de tegenwaarde is van het uitstel der werkelijke dekking.

$\left.{ }^{2}\right)$ Dlt laatste was de overheerschende vraag bij de conversieleening van 1896. Men had toen natuurlijk behooren door te gaan met de aflossing gelijk die in zake de geconverteerde leeningen geregeld was, doch wijl men nog niet tevreden was met de bate van de renteverlaging, begon men weer met $0.35 \mathrm{pCt}$. als eerste aflossingsbedrag, terwijl de amortisatie der leeningen van 1886 en 1892 te zamen reeds $0.45 \mathrm{pCt}$. was geworden door het toevoegen van de vrijgevallen rente aan de amortisatiebedragen. 
schuld was gewoonlijk gedurende een reeks van jaren langzaam tot het te consolideeren bedrag opgeloopen. Gunstige Staatsrekeningen hadden met ongunstige afgewisseld. Menig maal waren de als buitengewone aangekondigde uitgaven door de gewone inkomsten van het jaar zelf of van een volgend jaar gedekt; daarnaast waren er jaren geweest, waarin zelfs niet alle gewone uitgaven door gewone middelen waren gedekt, maar meestal was er toch over een aantal jaren te zamen wel een deel der tot buitengewoon gerekende uitgaven door gewone ontvangsten opgewogen. Voor welke van al de buitengewone uitgaven der verloopen jaren werd er nu geleend? Voor gindsch werk, dat, naar te verwachten is, wel een eeuw lang directe baten in de schatkist zal brengen of voor dat andere, dat men wel gaarne ongedaan zoude maken, omdat het in de praktijk verre van productief ${ }^{1}$ ) integendeel een geldverslinder bleek te zijn, dus wel zoo gauw mogelijk uit gewone middelen werkelijk gedekt mocht worden? Het was eenvoudig niet uit te maken en daarom was zeker wel het gemakkelijkst bij het bepalen van den aflossingstermijn met de vraag: "waarvoor is er geleend" in het geheel niet, of uiterst weinig, rekening te houden.

In dit opzicht zijn de gemeenten verre bij den Staat vooruit. Er bestaat voor gemeenten, die meestal toch niet op de groote geldmarkt kunnen komen, minder reden om het leenen uit te stellen totdat er een groot bedrag noodig is. Zij leenen daarom dikwijls en weten dan precies, waarvoor zij leenen; dekken van buitengewone uitgaven door gewone middelen in gunstige jaren komt bij haar niet voor; wat op den gewonen dienst overschiet brengen gemeenten over als inkomst op een volgenden dienst, gelijk zij tekorten op den gewonen dienst van eenig jaar in een volgend jaar als uitgaaf op haar begrooting brengen en alsdan door gewone middelen dekken. Men kan dus bij het bepalen van den aflossingstermijn rekening houden met het onderwerp, waarvoor geleend wordt en waar het toezicht van Gedeputeerde. Staten goed is, wordt er strenge contrôle ge-

1) Productief hier in den, m. i. eenig juisten, zin van meer diensten dan ondiensten (onderhoud en andere lasten). bewijzende. 
houden, dat de aflossingstermijn van de verschillende deelen der leening in geen geval langer is dan de vermoedelijke duur van de verschillende werken, waarvoor geleend wordt.

Nog een andere trek in het stelsel van leenen van den Staat is in strijd met het begrip, dat leenen slechts een middel is om een uitgaaf in een reeks van jaren in plaats van terstond, ten laste van de gewone middelen te brengen. Wil men de dekking van de kosten van aanschaffing van een zaak over een aantal jaren verdeelen, omdat die zaak zelf een aantal jaren zal dienst doen, dan is het toch zeker wel een eisch van goed beleid, dat reeds in het eerste jaar, waarin de zaak diensten bewijst, de gewone inkomsten gebruikt worden voor dekking van een deel van de kosteri van het werk. Zulks geschiedt, wanneer men, gelijk de meeste gemeenten, terstond leent, als de zaak wordt betaald, en dadelijk met aflossing van de leening aanvangt. Maar het geschiedt allerminst als men, gelijk bij den Staat, in de tekorten eerst jaren achtereen voorziet door een langzaam toenemende vlottende schuld, welke slechts afgelost wordt om door nieuwe te worden vervangen, doch die niet doelbewust wordt afgelost ten laste van de gewone inkomsten van den Staat. Van de kosten van menig werk komt het eerste gedeelte eerst ten laste van de gewone inkomsten een tiental of meer jaren, nadat het werk aanving zijn diensten te bewijzen. In werkelijkheid heeft men dan op het Staatsvermogen ingeteerd, want de zaak zelve waarvoor geleend wordt, verloor reeds een deel van hare waarde, terwijl de schuld nog op het volle bedrag bleef.

Dat wij, door op onze beurt werken uit te voeren op kosten van de gewone middelen, welke weder vele diensten zullen bewijzen aan het nageslacht, eveneens slechts op een zeer globale wijze betalen voor het genot van de werken, welke zij, die voor ons kwamen, uit hun gewone middelen betaalden, en dat wij door deze wijze van betalen al uiterst weinig kans hebben niet te weinig en ook niet te veel op de tegenwoordige contribuabelen te leggen, behoeft wel geen betoog. Een gebrek van deze wijze van doen is trouwens ook, dat de verleiding zoo groot is om de financieele verplichtingen, welke men in dezen vorm heeft te vervullen, slecht na te 
leven: Aan een eenmaal aangenomen regeling van amortisatie 1) (zij moge dan te gering of te groot zijn, gelet op den nuttigheidsduur der zaken, waarvoor de betrokken leening gesloten is) is men gebonden; men kan er niet in ongunstigen zin van afwijken. Maar aan de plicht om het Staatsvermogen op peil te houden door hetgeen vervanging behoeft, uit gewone middelen te bekostigen, is het, in tijden van verstoring van het budgetair evenwicht, uiterst verleidelijk zich min of meer te onttrekken. Bijna elke vernieuwing of vervanging van een gebouw of werk gedoogt wel eenig uitstel. Kosten voor nieuwe gebouwen of werken, tot vervanging van gebouwen of werken, die niet meer voldoende zijn, zijn dan ook steeds de uitgaven welke, indien er voor het budgetair evenwicht bezuinigd moet worden, het eerst worden geschrapt en tot gunstiger tijdstippen worden uitgesteld. Men heeft daardoor nog het bijkomende nadeel, dat men, om toch behoorlijk in den dienst te kunnen voorzien, overgaat tot zeer onzuinige tijdelijke maatregelen (oplappen of kleine uitbreiding van het oude gebouw of wel huren van meerdere ruimte). De huisvesting van een gedeelte van bijna alle onze departementen in filialen, welke weer afzonderlijke concierges, boden enz. vorderen, zijn hiervan een sprekend voorbeeld.

Teu slotte kan door zulk uitstellen de achterstand wel eens zoo groot worden, dat men er zonder leenen voor vervangingswerken niet meer komt en het beginsel, waarop het financieel systeem berust, komt dan in de verdrukking d. w. z. de tegenwoordig contribuabelen verzuimen hun plicht om tegenover het gratis genot van wat hun voorgangers stichtten, op hunne beurt het Staatsvermogen uit de gewone inkomsten op peil te helpen houden.

Op welke wijze kan men nu aan al die gebreken van onze tegenwoordige inrichting tegemoetkomen en geraken tot een stelsel, waarbij men nauwkeurig, althans veel nauwkeuriger, elk jaar kan zien wat men feitelijk doet, of men oplegt dan wel inteert, en waarbij men dus zoowel het interen als het opleggen, indien hiertoe geen over-

1) Of afschrijving. 
wegende reden aanwezig ') is, achterwege kan laten?

Mijn antwoord luidt door wat de hoofdlijnen betreft, de boekhouding meer in te richten op de wijze, waarop zulks steeds geschiedt door groote bedrijven, veelal ook door kleiner bedrijven en soms zelfs door particulieren, die er prijs op stellen zich nauwkeurig rekenschap te geven of hun vermogen toeneemt dan wel afneemt.

Zoodanige boekhouding beperkt zich niet slechts tot ontvangsten en uitgaven in geld en tot de schulden, doch omvat ook de waardeverminderingen en -verminderingen van de overige vermogensbestanddeelen, $Z \mathrm{Zij}$ verbiedt tot toeneming of achteruitgang van rijkdom te besluiten uitsluitend op grond van het toenemen of afnemen van de kas en de schuld.

Men zal wellicht opmerken, dat ook nu reeds de Staat wel met iets meer rekening houdt dan met den stand der kas en de saldi van de inkomsten en uitgaven, bewijze de splitsing van de uitgaven en inkomsten in gewone en buitengewone; bij de jaarlijksche becijfering van het vermoedelijk tekort op den komenden dienst en het gebleken tekort op afgeloopen diensten, en voorts dat de Staat toch bezwaarlijk elk jaar een balans kan opmaken van zijn schulden en bezittingen.

Ik zal noch het eene noch het ander tegenspreken, maar, al wenscht men voorloopig nog niet zoover te gaan als Italië, dat indertijd in de richting stuurde van een volledige balans, daarom behoeft men toch niet te blijven stilstaan bij de gebrekkige wijze, waarop er nu rekening mede wordt gehouden, dat niet alle uitgaven en inkomsten hetzelfde karakter dragen en dat, wat de Staat bezit, als alle dingen, gaandeweg in waarde vermindert.

Wanneer wij voor de toekomst een meer rationeel systeem willen om rekening te houden met wat ik, bij analogie, met bedrijven zoudto willen noemen de kapitaalsuitgaven (en -inkomsten) en de exploitatie-uitgaven (en -inkomsten) van den Staat, dan is het noodig, dat wij een weg zoeken

1) B. v. gedurende en kort na oorlogen of ander dergelijk groote rampen; interen is dan onvermijdelijk gedurende, weder bijeensparen van het ingeteerde nà afloo op van den buitengewonen toestand. 
om met de waardevermindering van de bezittingen van den Staat rekening te houden anders dan door aflossing van leeningen en door gedeeltelijk rechtstreeks uit onze gewone middelen te betalen wat niet slechts in het betrokken jaar doch ook in vele volgende nut zal doen.

Vinden wij een systeem om eenigszins nauwkeurig de werkelijke dekking der kosten van alle duurzame werken en inrichtingen, die wij van nu af aan bouwen, over de jaren te verdeelen, waarin zij zoo goed als zeker nut zullen doen, dan kunnen wij dat systeem niet alleen toepassen op de zaken, waarvoor thans pleegt geleend te worden, doch op alle zaken van duurzamen aard, die een noemenswaard bedrag kosten. $\mathrm{Er}$ is dan nog maar te zorgen, dat het tegenwoordig geslacht toch ook belast wordt wegens de lusten van al de zaken, welke het vond zonder dat er leeningen tegenover stonden, m.a.w. dat het op een of andere wijze de waardevermindering van de vroeger niet met geleend geld betaalde zaken bijpast, opdat er niet in het overgangstijdperk worde ingeteerd. Immers het is ook op zich zelf reeds niet wenschelijk, dat in het overgangstijdperk van het tegenwoordig naar een nieuw systeem van boekhouding het tegenwoordige geslacht tijdelijk ontlast wordt. Ruimte van middelen op den gewonen dienst geeft maar aanleiding tot stijging van uitgaven en deze zou zeer bedenkelijk zijn, wanneer de ruimte op de begrooting slechts tijdelijk zou zijn en elk jaar, naar gelang het nieuwe systeem verder in werking trad, minder zouden worden.

Wij hebben reeds gezien, dat het voor den Staat vrijwel onmogelijk is om bij het vaststellen van de aflossingstermijnen van leeningen eenig\$zins nauwkeurig rekening te houden met den vermoedelijken nuttigheidsduur van de zaken waarvoor geleend wordt. Trouwens de Staat is de eenige niet voor wien dat moeilijk is. Een groote scheepvaartonderneming en meer nog een spoorwegonderneming of groot fabrieksbedrijf zouden evenmin, door een, bij het àangaan der leening vastgesteld, bedrag voor aflossing van haar schuld ten laste van de Winst- en Verliesrekening te brengen, deze naar behooren kunnen belasten met de waardevermindering van hare bezittingen.

Een andere oplossing moet dus worden gezocht en deze 
is in hoofdzaak bereids gevonden bij de voorstellen in zake de spoedige afwerking van de stelling van Amsterdam en betreffende de kustverdediging.

Beginsel van die voorstellen was, dat de werken niet in de jaren, waarin ze gemaakt werden, ten laste van de gewone inkomsten konden worden gebracht, maar dat het anderzijds toch ook niet aanging om ze zonder meer onder de buitengewone uitgaven te brengen, zoodat er voor geleend zoude worden en de eigenlijke dekking uit de gewone inkomsten op een onzeker tijdstip zoude beginnen (n.l. als de schuld geconsolideerd zoude worden) en alsdan nog geen verband zoude houden met den duur van de werken. De betaling van de werken uit gewone inkomsten moest dus los gemaakt worden van de leening, die wellicht te eeniger tijd mede voor die werken zoude moeten gesloten worden. De kosten nu worden volgens de desbetreffende wetsontwerpen gebracht ten laste van eene afzonderlijke rekening, (fonds), hetwelk telken jare uit de gewone middelen een bedrag ontvangt voldoende om in het aantal jaren, dat de werken naar alle waarschijnlijkheid nut zullen doen, de kosten der werken met de rente, welke er inmiddels op gekomen is, te betalen.

Het fonds zelf ontleent zijn gelden aanvankelijk grootendeels aan de algemeene Staatskas als voorschot tegen vergoeding van rente (onafhankelijk van de vraag of de Staatskas voor de verstrekking van de gelden zelve leenen moet of niet) en restitueert ze aan de Staatskas naar gelang het daartoe in staat is. Dit bankiersbedrijf van de schatkist tegenover het fonds staat gelijk met hare bankierswerkzaamheden ingevolge de Woningwet. De gewone dienst staat er geheel buiten.

Men zou dit systeem kunnen toepassen voor elk werk, waarvan men de kosten niet terstond uit de gewone middelen dekken wil. Het is echter duidelijk, dat er dan een zeer groot aantal fondsen zoude ontstaan, alle met hun afzonderlijke begrooting en rekening en met hun eigen afrekeningen met de schatkist, en dat alle overzicht over de financiër op die wijze zoude zoekraken.

Doch het is ook niet noodig. Wil men het systeem, thans voor de kustverdediging voorgesteld, meer algemeen maken, dan stichte men ééne algemeene rekening voor buitengewone 
uitgaven d.w.z. men make de splitsing tusschen buitengewone en gewone uitgaven en ontvangsten, welke thans alleen in beschouwingen omtrent de financiën in de Millioenennota voorkomt, officieel ook in de begrootingen zelf.

Ik stel mij de zaak als volgt voor. Elk der 12 hoofdstukken van de Staatsbegrooting en de Middelenwet worden verdeeld in eene afdeeling $A$ en eene afdeeling $B{ }^{1}$ ). In de afdeeling $\mathrm{B}$ worden gebracht alle werken en inrichtingen, welke b. v. ten minste f 25.000 kosten en een vermoedelijken nuttigheidsduur hebben van ten minste 10 jaar. De afdeeling A van de hoofdstukken, waarop nu al die werken niet meer voorkomen, vormen te zamen de gewone begrooting van uitgaven, te dekken door de gewone middelen en de afdeelingen $\mathrm{B}$ te zamen de buitengewone begrooting te dekken door hare eigen inkomsten (de afdeeling B der Middelenwet.) Eene eerste plaats onder deze laatste inkomsten zouden moeten innemen de sommen, waarmede de gewone dienst zoude zijn te belasten ter zake van de in vorige jaren op den buitengewonen dienst gebrachte werken.

Stel er wordt besloten een rechtsgebouw te $A$ te bouwen; de gelden, f 300.000 , komen op de buitengewone afdeeling van Hoofdstuk IV. Nu moet er, tegelijk met het uittrekken van den eersten termijn voor den bouw, worden bepaald, in hoeveel jaren de kosten van het gebouw uit de gewone inkomsten moeten worden gedekt. Nemen wij aan dat voorzichtigheidshalve 20 jaar wordt aangenomen en dat als rentevoet voor dergelijke berekeningen is vastgesteld $3.5 \mathrm{pCt}$. De gewone begrooting van Hoofdstuk IV zal dan gedurende 20 jaar voor rente en aflossing in zake het rechtsgebouw te A moeten worden belast met een annuiteit van $7 \mathrm{pCt}$. van $f 300.000^{2}$ ) welke annuiteit als inkomst van het fonds voor buitengewone uitgaven wordt geboekt. Dit zelfde geschiedt ter zake van alle gebouwen en werken, zoo van Justitie als van andere Departementen. Het fonds voor buitengewone uitgaven zal op die wijze belangrijke uitgaven krijgen

1) Voor de bestaande verdeeling ran Hoofdstuk VII in A en B moet een andere nomenclotuur aangenomen worden.

${ }^{2}$ ) Of wel. $g_{0}^{\prime}$ van $f 300.000$ plus $3 ! \mathrm{pCt}$. over een jaarlijks net f 15.000 verminderend bedrag. 
doch reeds na weinige jaren ook zeer belangrijke inkomsten, waarbij natuurlijk ook gevoegd worden de inkomsten, welke thans reeds als buitengewoon gelden (opbrengst van verkochte domeinen, bijdragen van derden in de uitgaven voor buitengewone werken en terugontvangst van uit buitengewone middelen verstrekte voorschotten) en de na te noemen sommen van afschrijving op reeds bestaande zaken.

Wat het fonds te kort komt zoude door leening zijn te vinden, terwijl in jaren, waarin de rente en afschrijving, welke ten laste van den gewonen dienst en ten bate van den buitengewonen dienst komen wegens werken in vorige jaren gesticht, het bedrag te boven mochten gaan, dat voor nieuwe buitengewone werken noodig is, dus het surplus der ontvangsten van het fonds, voor amortisatie zoude moeten dienen.

Het behoeft wel geen betoog, dat in dit stelsel de maximumtermijn van aflossing der leeningen, m. a.w. het bedrag, dat jaarlijks ten minste moet worden geamortiseerd, van geen belang is.

Behalve voor zoover zulks noodig is om de leening aangenaam te maken voor het publiek, kan verplichte aflossing zelfs geheel achterwege blijven, en de aflossing beperkt blijven tot jaren, zooals boven bedoeld, waarin er minder uitgaven ten laste van het fonds voor buitengewone uitgaven worden gebracht dan dit fonds inkomsten heeft. In zoodanig jaar toch moet men aanniemen, dat de waarde van de bezittingen van den Staat afneemt. Immers de ontvangsten van het bedoelde fonds vertegenwoordigen de waardevermindering van de bezittingen van den Staat, de uitgaven de waardevermeerdering. Als echter de waardevermindering grooter is en dus de waarde van de bezittingen van den Staat afneemt, moet de schuld voor de aanschaffing dier bezittingen aangegaan, eveneens afnemen.

Het fonds ontvangt, met betrekking tot elke inrichting, die er uit bekostigd is, op rekening van den betrokken tak van dienst een bedrag gelijk aan de rente en aflossing, als er noodig zoude zijn om een leening te delgen, speciaal voor de bekostiging van die inrichting gesloten. De rente bezigt het fonds voor betaling van, rente van nationale schuld, het bedrag der aflossing bezigt het òf 
(in de meeste gevallen) tot betaling van nieuwe buitengewone werken, waarvoor dus niet geleend behoeft te worden of, zijn er zoodanige niet of niet genoeg, tot aflossing van nationale schuld.

Hieruit volgt, dat de rente en aflossing der Staatsleeningen onder vigeur van dit stelsel aangegaan, niet meer uit den gewonen dienst behoeven te worden betaald doch ten laste van het fonds voor buitengewone uitgaven komen.

Ik merk hierbij op, dat wat hier voorgesteld wordt in hoofdzaak overeenkomt met hetgeen particuliere bedrijven doen. Een stoomvaartmaatschappy b. v. belast jaarlijks haar winst- en verliesrekening met een bedrag gelijkstaande met de vermoedelijke waardevermindering van de schepen. Dat bedrag blijft in kas, totdat het wordt gebezigd of voor aanschaffing van nieuwe schepen of andere inrichtingen of wel - indien het n. l. voor dat doel vooreerst niet noodig is - tot aflossing van schuld. Indien er telkens nieuwe schepen noodig zijn en er geen bepaalde aflossing van schuld tegenover de obligatiehouders verplicht is, dan blijft de leening aan de creditzijde van de balans steeds even groot doch aan de debetzijde, komen er in den loop van den tijd telkens andere schepen als contrapost van de leening te staan. Bijft de waarde der bezittingen steeds even groot, dan kan ook de schuld even groot blijven en eventueel verplichte amortisatie kan geschieden uit de opbrengst van een nieuwe leening tot gelijk bedrag als er geamortiseerd wordt.

Slechts verschilt het voorgestelde systeem van Staatsboekhouding in zooverre van dat van groote bedrijven, dat ook de rente van. schuld, welke de Staat nog heeft tegenover zekere bezitting, ten laste wordt gebracht van den tak van dienst, welke van die bezitting gebruik maakt. Wij. zullen straks zien, waarom deze uitbreiding wordt voorgesteld.

Natuurlijk zoude men het systeem verder kunnen doorvoèren dan voor werken van f 25.000 en ten minste 10 -jarigen duur. Men kan, het werd reeds betoogd, de kosten van inktkokers en pennehouders, welke meer dan een jaar bruikbaar blijven, over de jaren, waarin zij dienst doen verdeelen. Doch hierdoor zoude men de zaken onnoodig 
omslachtig maken. In hoe kleiner soort benoodigdheden men komt, hoe grooter de zekerheid, dat in een zeer omvangrijk financiewezen, de jaarlijksche uitgaven daarvoor tamelijk constant (wellicht constant stijgende) zijn. Bij de gemeenten, die feitelijk vrijwel het aanbevolen systeem volgen, zij het dan, dat zij afschrijven in den vorm van aflossen, ziet men dan ook dat het al of niet leenen voor zaken van eenigen duur afhangt van de verhouding tusschen de uitgaven voor eenige zaak en het eindcijfer van het budget. Zeer kleine gemeenten leenen, zij het op. een tamelijk korten termijn, voor het vernieuwen van een klein stuk dorpstraat of aanschaffing van een kostbaar secretariemeubel (een loket- of brandkast). Eenigszins grootere gemeenten gaan niet zoover met de verdeeling over meer jaren van de dekking van uitgaven voor kleine zaken, die eenige jaren nut doen, doch alweer veel verder dan zeer groote gemeenten, die zaken, welke duizenden guldens kosten, op den gewonen dienst brengen, omdat het regelmatig terugkomen daarvan zóó zeker is, dat een systeem van verdeeling der dekking, tot dezelfde resultaten zoude leiden als het rechtstreeks elk jaar betalen uit de gewone middelen en omdat de verleiding tot ontlasting der begrooting door ze één jaar niet uit te trekken niet groot is, wijl uitstel van aanschaffing den dienst in de war zou brengen. Ook bij bedrijven zien wij hetzelfde. Een klein bedrijf met goede boekhouding, zal nieuwe gereedschappen die eenige jaren meegaan, wèl ten laste der kapitaalrekening brengen, een groot bedrijf, waarbij elk jaar de aanschaffing van een groot aantal gereedschappen onvermijdelijk is, brengt ze op de exploitatierekening.

Gaan wij thans de voordeelen na, welke het aanbevolen systeem biedt naast het hoofdvoordeel, dat het mogelijk maakt om met de waảrdevermindering van elke bezitting van den Staat afzonderlijk rekening te houden zonder dat men de aflossing der leeningen behoeft te regelen naar den duur van de zaken, waarvoor men leent.

Een eerste voordeel van een afzonderlijk fonds voor buitengewone uitgaven zoude zijn, dat alle deelen van de wetgevende macht effectiever medezeggingsschap zouden 
krijgen in de financieele politiek. Gelijk de zaken thans gaan, is de Tweede Kamer feitelijk zonder middelen om in details over de financieele politiek te beslissen. In de Memorie van Antwoord van de Bedrijvenwet is zulks door den Minister van Financiën zeer juist uiteengezet. De Minister maakt in de Millioenennota een splitsing tusschen de uitgaven in gewone en buitengewone. De Kamer kan echter niet omtrent de rangschikking van elken post een beslissing nemen. Hare macht beperkt er zich toe om te betoogen, dat er te veel of te weinig als buitengewoon wordt gebracht. Somtijds kan zij hierover een beslissing uitlokken t. w. wanneer de Minister tijdelijke of blijvende middelen-versterking voorstelt en. de Kamer zich hiertegen verzet op grond, dat die versterking onnoodig zoude zijn, indien slechts de Minister voor meer zaken wilde leenen. Doch er is dan nog maar alleen uitgemaakt, dat er meer zaken als buitengewoon konden worden beschouwd, maar niet welke. En wanneer de Minister geen middelenversterking voorstelt, doch zijn enge opvatting van het begrip buitengewoon slechts leidt tot sterke beperking van de begrootingscijfers, die hij aan zijne ambtgenooten veroorlooft en eveneens, wanneer de Minister te véél zaken op buitengewoon brengt en dus voorstellen tot versterking der middelen achterwege laat, welke de Kamer noodig acht, omdat zij minder ruime opvatting van het begrip buitengewone uitgaven heeft, in al die gevallen is er geen gelegenheid tot het uitbrengen van een votum, waaruit de stemming van de Kamer blijkt. Tenzij men tot moties van orde zijn toevlucht wil nemen, iets wat naar mijn weten nog nimmer is geschied, al komen individueele beschouwingen over een te ruime. of te enge opvatting van het begrip buitengewoon nagenoeg elk jaar bij de behandeling der begrooting voor.

Men zal wellicht zeggen: „wanneer eenmaal bepaald wordt, dat uitgaven voor werken, welke meer dan f 25.000 kosten en meer dan tien jaren nut doen, ten laste van het fonds voor buitengewone uitgaven zullen worden gebracht, wat blijft er dan nog voor de Volksvertegenwoordiging telken jare te beslissen?" Het antwoord luidt: de wetsbepaling heeft slechts de beslissing eenigszins verplaatst. $\mathrm{Na}$ haar inwerkingtreding ligt het zwaartepunt van de financieele 
politiek in de bepaling van den tijd, binnen welken en den vorm, waarin (annuiteit of jaarlijks vast bedrag voor afschrijving) de uitgaven voor een werk ten laste van den gewonen dienst moeten worden gebracht en de Kamer zal er volledig en praktisch medezeggingsschap in hebben, doordat zij voorstellen der Regeering ter zake zal kunnen amendeeren.

Een tweede voordeel is; dat beter dan thans een inzicht in de begrooting is te verkrijgen en tegen opdrijving met schijn-zuinigheid kan gewaakt worden.

Schijn-zuinigheid is er niet zelden, doordat men uitgaven, die niet regelmatig terugkeeren, maar die onvermijdelijk binnen korten tijd moeten geschieden, uitstelt en daarentegen een zij het geringer aantal jaarlijks terugkeerende uitgaven opneemt. Het is een niet te ontkennen feit, dat wanneer de voorloopige begrootingen opgemaakt zijn en gezamenlijk tot een totaalcijfer komen, dat hooger is dan de Minister van Financiën, gelet op de raming der middelen, kan toelaten, zoodat er op de voorloopige begrootingen moet geschrapt worden, zoo goed als nimmer de uitbreiding van een diensttak, of een algemeene reorganisatie van een ambtenarencorps met verhooging van de tractementen, of wel kleinere verhoogingen van uitgaven voor personeel worden teruggenomen, doch de besnoeiïng bijna altijd geldt uitgaven voor werken en inrichtingen, die bereids onder handen zijn, of een volgend jaar onmogelijk meer uitgesteld kunnen worden.

Het is voor wie ook bijna ondoenlijk om de verschillende hoofdstukken der staatsbegrooting zóó uit te pluizen, dat hij afdoende de vraag kan beantwoorden, of een begrooting met een lager of slechts weinig hooger eindcijfer nu inderdaad, voor wie verder dan een jaar kijkt, zuinig opgemaakt is. Het komt zelfs voor bij de departementen, die maar zelden een belangrijk werk hebben, zoodat het overzicht gemakkelijk is te krijgen, dat het eene jaar de verhooging der eindcijfers wordt goedgepraat met verwijzing naar een bijzonder werk, terwijl er dan het volgend jaar een groot deel van het, nu vrijvallend, bedrag wordt gebruikt voor blijvende uitgaven en nog met eenige zelfgenoegzaamheid wordt opgemerkt, dat het eindcijfer lager is.

Een splitsing der uitgaven als het aanbevolen systeem 
medebrengt zal zoodanige schijn-zuinigheid zoo niet geheel dan toch grootendeels onmogelijk maken; niet slechts de controleerende Kamers zullen gemakkelijker een oog houden op de werkelijke lasten, welke zij voteeren doch ook de hoofden van departementen zelf zullen beter inzien wat hun door de verschillende diensttakken wordt voorgelegd.

Opgemerkt mag hier tevens worden, dat uitstel van het afwerken van een zaak altijd een onzuinige methode is.

Is er tot een werk besloten en zijn de eerste uitgaven gedaan, dan is het wenschelijk om het werk zoo spoedig mogelijk gereed te doen komen, opdat men de diensten van het werk geniete. Natuurlijk valt er rekening te houden met het tempo, waarin het werk uit technisch oogpunt het goedkoopst kan worden gemaakt, maar dit mag niet alleen beslissen. Zoo lang het echter geen werken geldt van zoodanigen omvang, dat ook rekening is te houden met de mogelijkheid om de gelden op de geldmarkt te verkrijgen, (wat b.v. bij een zeer spoedige uitvoering van de drooglegging der Zuiderzee van invloed zou kunnen zijn) mogen overwegingen aan de jaarlijks op de begrooting beschikbaar te stellen sommen niet van invloed zijn op het tempo van het werk; (ten minste niet als men volgens het aanbevolen systeem en hetgeen hierna nog volgt heeft gezorgd, dat elk jaar zijn gerecht deel toch te dragen krijgt).

Een derde voordeel van het aanbevolen stelsel is, dat beter dan tot dusverre blijkt aan welke zaken feitelijk de Staatsinkomsten besteed worden. Bij het tegenwoordige systeem blijkt zulks bij die takken van dienst, waarbij werken voorkomen, voor welke geleend wordt, allerminst.

In het jaar, waarin de uitgave wordt gedaan wordt zij bij de buitengewone uitgaven gerekend en aldus niet aan het departement toegerekend op welker begrooting zij voorkomt. En in latere jaren? Ook dan treft men op den gewonen dienst van dat departement daaromtrent niets aan. De werkelijke betaling der uitgaaf vindt men dan in de renten en aflossing der Staatsleening welke ter zake is aangegaan, dus op Hoofdstuk VII A.

Zoo geeft dan ook b.v. het IXde Hoofdstuk der Staatsbegrooting slechts een zeer onvolkomen beeld van hetgeen de Waterstaat inderdaad jaarlijks kost. Men zoude om tot Fcon. 1912. 
een zuiver beeld te komen de rente en aflossing van leeningen voor Waterstaatswerken, b.v. de Nieuwe Maasmond, de Rotterdamsche Waterweg, het Merwedekanaal en het Noordzeekanaal aangegaan, moeten voegen bij de bedragen, welke jaarlijks op den gewonen dienst van Hoofdstuk IX voorkomen.

Bij het aanbevolen stelsel zullen jaarlijks op de begrooting van elk departement (ja van elken tak van dienst ressorteerende onder een departement) de werkelijke lasten drukken, welke de verschillende werken inderdaad dat jaar van den Staat vorderen. In den overgangstoestand - waarover straks - zal zulks wellicht nog onvolkomen zijn, doch: telken jare zal de begrooting in hoogere mate een beeld geven van de werkelijke kosten van elk onderdeel van het staathuishouden. De toestand zal als het ware zijn, alsof elk departement de inrichtingen van langdurig nut huurde van het fonds voor buitengewone uitgaven en als huurprijs betaalde: de afschrijving, welke op die inrichtingen moet plaats hebben en de rente van het bedrag, dat voor de stichting besteed en nog niet afgeschreven is.

In de vierde plaats zullen verschillende financieele transacties veel overzichtelijker en duidelijker in de begrootingen en rekeningen kunnen uitkomen. I $\mathrm{k}$ heb het oog op de toenemende bankierszaken, welke de Staat verricht. Nemen wij den Staat als bankier ingevolge de Woningwet. Wat hij voorschiet aan gemeenten voor woningbouw kan naar algemeen oordeel worden gerangschikt onder de buitengewone uitgaven, waarvoor geleend mag worden. Hoe nu echter met hetgeen de Staat terugontvangt van de gemeenten? Moet dit als buitengewone ontvangst of als gewone ontvangst worden geboekt? Het antwoord is thans, nu de aflossing van de Staatsleeningen uit de gewone middelen geschiedt, niet terstond te geven. Beschouwt men de geheele terugbetaling van de gemeenten als een buitengewone inkomst, dan vormt men kapitaal voor het nageslacht. Immers men heeft dan na zekeren tijd het kapitaal aan de gemeenten geleend terug en in nieuwe bezittingen of voorschotten belegd en tevens heeft men de schuld, welke de Staat zelf aanging om aan de gemeente geld te kunnen voorschieten, uit zijn gewone middelen afgelost. 
Brengt men daarentegen de terugbetalingen van de gemeenten als gewone ontvangst, dan is er gevaar dat men kapitaal vernietigt, want dat de Staat na een aantal jaren het aan de gemeenten voorgeschotene terug heeft, maar dat de schuld, die hij zelf aanging om voorschotten te kunnen geven, nog gedeeltelijk bestaat. Als de Staat elk jaar juist het bedrag leende, dat hij aan gemeenten voorschiet en op gelijken termijn het geld leende en voorschoot, dan z.oude het eenvoudig genoeg zijn om te zorgen, dat deze bankierstransactie noch op kapitaalvorming noch op kapitaalvernietiging uitliep, maar het is verre van dien en er zal dus in het tegenwoordige stelsel altijd bij benadering moeten worden bepaald, welk deel van de terugbetaling van voorschotten geacht moet worden een buitengewone en welk deel een gewone ontvangst te vormen. Zoo is het met al de bankierszaken, met de voorschotten ingevolge de Tiendwet, met de voorschotten aan Suriname en als de Bedrijvenwet wordt toegepast ook met de kapitaalverstrekking aan de bedrijven.

In het voorgestelde stelsel vervalt dat bezwaar. De bankierszaken loopen zoowel in ontvang als in uitgaaf geheel over de "Rekening van buitengewone uitgaven". Voorzoover de uitgaafzijde betreft, wijken zij in zooverre af van de andere buitengewone uitgaven, dat er niet op behoeft te worden afgeschreven ten laste van den gewonen dienst. Moet eene door leening gedekte uitgave voor een gebouw in een aantal jaren ten laste van den gewonen dienst worden gebracht, omdat het gebouw in waarde daalt door het ouder worden, een vordering op een gemeente daarentegen behoudt hare waarde voorzoover zij niet afgelost wordt; het is dus voldoende, dat de aflossing door de gemeente aan de Buitengewoon-rekening ten goede komt om de zaak in evenwicht te houden. Slechts op vorderingen, welke om een of andere reden dubieus zijn te achten, moet ten laste van den gewonen dienst afgeschreven worden (b.v. de rentelooze voorschotten voor tramwegen).

Het stelsel maakt trouwens ook mogelijk om voor aankoop van onroerend goed, waarop afschrijving in het algemeen niet noodig is, de afschrijving achterwege te laten. Natuurlijk moet daar dan echter tegenover staan, 
dat de opbrengst van onroerend goed, dat de Staat verkoopt, steeds ten volle aan den buitengewonen dienst ten goede komt en dus strekt tot schuldvermindering of voorkoming van schuldvermeerdering.

Eindelijk zij nog als voordeel van het systeem vermeld, dat het in een zelfde jaar leenen en aflossen zooveel mogelijk wordt voorkomen. De verplichte aflossing op de bestaande leeningen zal natuurlijk moeten worden voortgezet, doch van eventueele nieuwe leeningen zal verplichte aflossing kunnen achterwege blijven. Hetgeen in het oude stelsel voor amortisatie zoude zijn te bestemmen als aequivalent van de waardevermindering der bezittingen, zal in het nieuwe stelsel kunnen worden gebruikt voor nieuwe werken, waarvoor anders geleend zou moeten worden.

Men valt dus de geldmarkt uitsluitend lastig wanneer en voor zoover er tegenover uitbreiding van bezittingen uitbreiding van schuld mag staan.

Erkend moet worden, dat er financiers zijn, die het van belang achten, dat er voortdurend in de staatsschuld ter beurze veel omgaat en die daarom leenen eenerzijds en aflossen anderzijds wenschelijk vinden. Ik meen mij echter te moeten aansluiten bij hen, die het aan de markt brengen van nieuwe schuld grooter kwaad achten voor de koersen der staatsschuld dan het inkoopen voor amortisatie daarvoor een voordeel is.

Hoewel geen volstrekte consequentie van de aanvaarding van het geschilderde stelsel van begrootingen, is het toch zeer wenschelijk, dat daarmede nog eene andere wijziging in het bestaande systeem der begrooting gepaard ga, met name dat, gelijk reeds bij gemeente en provincie geschiedt, ook de Staat verband gaat leggen tusschen de diensten van de opvolgende jaren.

Thans wordt bij den Staat elk dienstjaar als een afzonderlijke zaak behandeld en ook de resultaten worden afzonderlijk gehouden ${ }^{1}$ ). De voor- en nadeelige saldi, waarmede

1) Gelukkig gaan wij niet zoover hiermede als in Frankrijk kort voor de revolutie. Elke dienst werd toen als een rechtspersoon beschouwd; sloot hij met' een te kort dan werden de crediteuren van den Staat wegens levering in dat dienstjaar, die hun geld nog 
de verschillende dienstjaren sluiten, worden niet op een volgend jaar als ontvangsten of uitgaaf gebracht, doch blijven geheel afzonderlijk in de lucht hangen. Daar in werkelijkheid de ontvangsten en uitgaven van alle dienstjaren in één kas vloeien en uit één kas geput worden, heefd inderdaad wel vermenging van die saldi plaats, doch administratief blijven zij afgezonderd. De voordeelige saldi zijn crediteuren de nadeelige debiteuren van de algemeene kas (vertegenwoordigd door de Generale Thesaurie). Zoo nu en dan - gewoonlijk kort na het sluiten van een leening - heeft een afboeking van die saldi ingevolge de wet plaats. De nog openstaande voordeelige saldi worden dan aangewezen om zooveel mogelijk de nadeelige te dekken en voor zoover er nog nadeelige overblijven, wordt de opbrengst van de leening (welke, behoudens zeer zeldzame uitzonderingen, nimmer onder de ontvangsten van een be-paald dienstjaar wordt opgenomen) aangewezen om die saldi te dekken. Na zulk een afrekeningswet verdwijnen de voor- en nadeelige saldi van de betrokken dienstjaren uit de boeken der Generale Thesaurie en wordt met het aankweeken van een nieuwe serie zwevende saldi begonnen.

Een afboeking als hier bedoeld, heeft thans in lange niet plaats gehad; al de voordeelige en nadeelige saldi van de dienstjaren na $1891 \mathrm{zijn}$ nog af te boeken.

Het is niet te ontkennen, dat deze handelwijze enkele voordeelen aanbiedt. Men houdt beter gezicht op de cijfers van elke begrooting op zich zelve, wanneer daarin geen voor- of nadeelige saldi van vorige dienstjaren zijn verwerkt. Daarenboven werkt het systeem, althans in de tijden van overschotten, soliede beheer wel in de hand. De overschotten blijven beschikbaar om hetgeen er wellicht van de uitgaven te veel en van de inkomsten te weinig op den buitengewonen dienst is gebracht, goed te maken. De overschotten toch komen niet in mindering van hetgeen in het volgend jaar tot dekking noodig is. Een groot aantal overschotten in vorige

niet hadden, afgescheept met een zeker percentage van hun vorderig, zoo groot als de nog beschikbare middelen van dat dienstjaar toelieten; recht op middelen van een vorig of volgend dienstjaar hadden $z \mathrm{ij}$ niet, het werd althans niet erkend. 
jaren moge al op het bedrag der dekking van een toekomstig jaar van invloed zijn, omdat zij lichter over een geraamd tekort zullen doen heenstappen, dit is toch maar een verwijderde invloed.

Echter denzelfden invloed ten gunste van een soliede beheer, die het systeem van afzonderlijk houden van de saldi heeft, als er jaren met voordeelige saldi zijn, dienzelfden invloed in omgekeerden zin, d. i. ten nadeele van een soliede beheer, heeft het, als er nadeelige saldi zijn. Dan worden de nadeelige saldi vergeten in plaats van in volgende jaren te. worden ingehaald.

Wordt nu door het door mij voorgestelde begrootingssysteem voldoende en op rationeele wijze, met behoorlijke kennis van den toestand, gezorgd voor soliede beheer, is na behoorlijk overleg vastgesteld, wat er wel en wat er niet door het nageslacht mede moet betaald worden, dan zijn de voordeelen van de afzonderlijke gehouden saldi geen. voordeelen meer, en zullen de nadeelen dubbel zwaar wegen. Er behoort dan niet meer, maar ook niet minder, uit gewone middelen betaald te worden dan men eenmaal heeft vastgesteld. Wat er in eenig jaar, doordat de uitkomst nu eenmaal altijd van de raming afwijkt, niet noodig is geweest of tekort is gekomen om de uitgaven te dekken, welke men, wèl overwogen, tot de gewone heeft gemeend te moeten rekenen, moet aan een volgend jaar aan de contribuabelen ten goede komen of in een volgend jaar door de contribuabelen aangevuld worden.

Tot zoover de bijkomstige voordeelen van het aanbevolen systeem.

Het zal intusschen, na al hetgeen hiervoor is gezegd, wel geen betoog behoeven, dat men het aanbevolen stelsel niet zal kunnen invoeren voor de toekomst alléén. Wanneer voortaan de kosten van alle werken van eenige beteekenis, welke een aantal jaren dienst zullen doen, ten laste van de gewone uitgaven van die toekomstige jaren zullen worden gebracht, dan moet er ook naar een middel worden gezocht om de eerstkomende jaren in billijke mate te belasten wegens genot van zaken in den verleden tijd gesticht, welk belasten thans zoo goed en zoo 
kwaad mogelijk geschiedt door aflossing van schuld en door het geheel ten laste van de gewone middelen nemen van een deel der zaken, welke-wij mede ten bate van de toekomst stichten.

Het beginsel toch moet streng gehandhaafd worden, dat het tegenwoordig staatsvermogen op peil gehouden worde.

In theorie is deze aangelegenheid gemakkelijk genoeg te regelen, wanneer wij eenmaal het fonds voor buitengewone uitgaven hebben. Wij hebben slechts te bepalen, dat jaarlijks de gewone dienst moet worden belast met een zeker bedrag wegens waardedaling van alle staatsbezittingen, waarvan nog nut getrokken wordt, terwijl dan in mindering daarvan kan komen wat inderdaad aan aflossing van schuld wordt betaald. M. a. w. we kunnen den toestand terstond trachten te verkrijgen, welke er thans zoude bestaan, wanneer reeds een halve eeuw of langer geleden het aanbevolen systeem van boekhouding ware aanvaard.

Een groote moeilijkheid is echter in de uitvoering gelegen. Bij de, in de toekomst te stichten, zaken zullen de kosten steeds bekend zijn en zal alleen de bepaling van den vermoedelijken nuttigheidsduur van elke zaak d. w. z. van den termijn, gedurende welken elke zaak vermoedelijk per jaar meer diensten zal bewijzen dan er aan ten koste behoeft te worden gelegd, eenige moeilijkheid medebrengen.

Doch bij de bestaande zaken moet men verschillende factoren schatten. Is de stichtingstijd nog betrekkelijk kort geleden, dan is wellicht mogelijk dezelfde methode te volgen als voor zaken, welke in de toekomst gesticht worden. Neemt men b. v. in het algemeen voor den duur van zekere soort werken 30 jaar aan, dan kan men van werken van die soort, welke 20 jaar geleden gesticht zijn, aannemen, dat er bereids 20 afschrijvingen hebben plaats gehad en op dien voet met de afschrijving doorgaan. De stichtingskosten zullen uit den aard der zaak nog gemakkelijk kunnen gevonden worden in de betrokken jaarrekeningen.

Doch moeilijker wordt de zaak ten aanzien van de vele werken en inrichtingen, welke reeds uit zeer ouden tijd afkomstig zijn.

Te onderscheiden zoude daarbij nog zijn tusschen gebouwen en andere werken. Voor gebouwen zal het niet te 
bezwarend zijn de waarde op een zeker oogenblik te schatten, rekening houdende met den termijn, gedurende welken zij vermoedelijk nog voor hunne tegenwoordige bestemming zonder noemenswaardige wijzingen dienst kunnen doen. Zoodanig schatting had voor eenigen tijd plaats van de gebouwen in gebruik bij de Posterijen. De schatting zoude den opstal en de terreinwaarde afzonderlijk moeten betreffen, vermits op de terreinwaarde als regel geen afschrijving noodig is.

Met betrekking tot andere inrichtingen en werken van ouderen datum, de spoorwegen uitgezonderd, is echter een eenigszins nauwkeurige berekening niet mogelijk. Men zal daarvoor een afschrijvingsbedrag in eens moeten aannemen, dat natuurliik in hooge mate willekeurig zal zijn.

Wellicht ware het beste aan te nemen, dat het bedrag aan aflossing, dat telken jare begrepen zoude zijn in de annuïteit, die noodig ware om de Nationale Schuld welke van vóór 1875 dateert (d. i. de geheele 21 pCt. schuld en ongeveer 80 millioen . van de $3 \mathrm{pCt}$. schuld) in honderd jaar af te lossen, aequivaleert met de waardevermindering van de Staatseigendommen, welke meer dan 35 jaar oud zijn, uitgezonderd de gebouwen en de spoorwegen.

Wat de spoorwegen betreft ware de jaarlijksche waardevermindering ongeveer te berekenen op den voet aangewezen door de Staatscommissie, welke onlangs verslag heeft uitgebracht omtrent het in spoorwegzaken te volgen beleid.

Brengt men de op deze wijze gevonden jaarlijksche afschrijving - welke afschrijving natuurlijk in den loop der tijden zal verminderen doordat voor verschillende objecten het tijdstip aanbreekt, waarop zij geacht kunnen worden geheel te zijn afgeschreven ${ }^{1}$ ) - ten laste van den gewonen en ten bate van den buitengewonen dienst, dan is het duidelijk, dat ook de aflossing van de bestaande leeningen ten laste van den buitengewonen dienst kan worden gebracht. In zake de oude werken, gelijk voor de nieuwe wordt voorgesteld, óók rente te brengen ten laste van de hoofdstukken der Staatsbegrooting, waarvoor de werken dienen en ten bate van het fonds voor de buitengewone uitgaven

1) Tijdstip, waarop enkele wellicht ook reeds verdwenen zïn. 
schijnt onuitvoerbaar, waaruit echter volgt, dat dan ook de rente van de oude leeningen ten laste van den gewonen dienst moet blijven.

Het lijdt wel geen twijfel, of de afschrijvingsbedragen waarmede de gewone dienst zal worden belast, zullen aanmerkelijk hooger zijn dan de aflossing op de bestaande leeningen, welke thans op den gewonen dienst drukken.

Dit meerdere nu zal dan in de plaats treden van hetgeen voortaan op den gewonen dienst niet meer zal voorkomen voor die vele werken en gebouwen, waarvan de kosten tot dusverre tot de gewone werden gerekend.

Of het eindresultaat zal zijn, dat de gewone dienst toch nog ontlast wordt (waaruit zoude volgen dat wij thans te soliede zijn) dan wel of de gewone dienst door de invoering van het aanbevolene aanvankelijk meer zal worden belast? Ik zoude daaromtrent niet gaarne een voorspelling doen. Er zal trouwens veel afhangen van de grondslagen, waarop de berekening van het afschrijvingscijfer over de reeds bestaande zaken wordt gebaseerd. Het wenschelijkst ware misschien, dat deze zóó gekozen werden, dat er zoomin ruimte van middelen als groote tekorten van middelen in de eerstvolgende jaren het gevolg van het nieuwe systeem zijn. Het ware daarom aan te bevelen, dat vooraf zooveel mogelijk de gevolgen werden becijferd. Slechts wanneer onaannemelijke grondslagen zouden moeten worden genomen voor de becijfering van het afschrijvingsbedrag om tot de gewenschte uitkomst te komen, zoude men zich moeten getroosten de werkelijkheid te aanvaarden, hetzij dan dat die was dat wij thans erg interen, hetzij dat overtuigend bleek, dat wij veel te soliede zijn. Gelet op de uitkomsten van de becijferingen in het conto-finto der zooeven genoemde staatscommissie schijnt er voor het laatste geen zeer groote kans.

Zijn toch de grondslagen van dat conto-finto juist, dan wordt er thans ter zake der spoorwegen een zestal millioenen per jaar ingeteerd. Er zoude dus overigens ten onzent in het tegenwoordig systeem meer dan 6 millioen kapitaal moeten worden gevormd, door dat bedrag meer aan blijvende zaken uit gewone middelen te betalen, en aan amortisatie te besteden, dan onze bezittingen in waarde afnemen.

Vraagt men mij, of het nieuwe systeem geheel zonder 
gevaren is, dan antwoord ik: allerminst. Vooreerst al is er gevaar, dat men in den overgangstoestand te weinig extra afschrijft op de reeds voor de invoering bestaande zaken. En verder is het verleidelijk om de afschrijvingen op de in den vervolge te maken gebouwen en werken over een te groot aantal jaren te verdeelen.

Intusschen wil het mij toch voorkomen, dat men dit bezwaar niet te zwaar moet laten wegen. Het is beslist niet wenschelijk, dat men de afschrijvingen op een gebouw of werk, waaraan eenige jaren wordt gebouwd, eerst begint nadat het geheel gereed is. Wel is zulks gebruikelijk - en terècht - in de particuliere boekhouding, doch bij den Staat zoude het verkeerd zijn, omdat dan meestal een Minister op zijne begrootingen geen last meer zoude hebben van de nieuwe werken, welke hij op touw heeft gezet en waarvan hij, al beleeft hij het gereedkomen niet, toch grootendeels de eer zal hebben. Men zal uiterlijk het jaar, volgende op dat, waarin het werk is begonnen, moeten beginnen den gewonen dienst te belasten met een afschrijving ter zake van het werk. Intusschen het bedrag van de afschrijving moet reeds het jaar, waarin tot het werk besloten wordt, vastgesteld worden en wijl men in dat jaar zelf de begrooting (gewonen dienst) nog niet behoeft te bezwaren, zal men geneigd zijn om op solide wijze een hoog afschrijvingscijfer vast te stellen.

Maar daarenboven, wat er aan ons parlementaire stelsel moge ontbreken, van een soliede financieel beheer, dat niet meer dan oirbaar is op de toekomst schuift, gaat toch langzamerhand elkeen hoe langer hoe meer de noodzakelijkheid inzien. Voorzoover nog het tegenovergestelde voorkomt, is zulks slechts het gevolg van, en slechts te handhaven door, de omstandigheid, dat de zaak aan de meesten niet duidelijk voor den geest staat en zij niet - of niet dan met veel arbeid - in staat zijn tot kennis van den waren toestand te geraken. In zulke gevallen geeft men zich niet veel moeite om te onderzoeken, of wel mag worden voortgegaan, zooals men bezig is.

Maar als het duidelijk is, hoe de zaken staan, als gemakkelijk te onderscheiden is, of het gevoerde beleid al dan niet soliede mag heeten, dan neemt toch bijna iedereen het 
eerder op voor een beheer., dat op behoorlijke basis staat dan voor handelingen, welke op den duur moeten leiden tot een slecht financiewezen. De tijd - zooals de eerste helft van de vorige eeuw - toen men, niet zelden bewust, een politiek van "après nous le déluge" volgde, of althans, nagenoeg tegen beter weten in, bij zijn sle ihte maatregelen de hoop koesterde, dat ze niet zoo nadeelig voor de toekomst zouden zijn als ze bij ernstig nadenken wel moesten geacht worden te zullen zijn en door de soliede financiers ook werden genoemd, die tijd is voorbij. De harde leerschool, die men toen heeft moeten doorloopen, werkt nog na en zal nawerken totdat op dit punt verstandig oordeel zóó algemeen is, dat de donkere tijden der $19 \mathrm{e}$ eeuw niet meer als afschrikkend voorbeeld behoeven te worden aangehaald.

I $\mathrm{k}$ zal daarom niet beweren, dat aanvaarding van het door mij gedachte stelsel van begrooting niet in den aanvang zal leiden tot eenigszins sterkere toeneming onzer staatsschuld dan tot dusverre. Maar ik acht zulks allerminst een kwaad. Toeneming der' Staatsschuld zal bij het aanbevolen systeem slechts denkbaar zijn wanneer de waarde (nuttigheid) van het Staatsbezit toeneemt, in tijden dus van expansie. En dan is daartegen geen bezwaar. Het wil mij voorkomen, dat ten onzent in de laatste kwarteeuw te groote schuwheid heeft bestaan om geld in de $\mathrm{zaak}$ te steken. Vergelijken wij ons met onze buren, dan verkeeren wij min of meer in den toestand van een groot industrieelof handelsbedrijf, dat door al te voorzichtige politiek niet met zijn tijd is meegegaan. België b.v. - al moge het in het andere uiterste vervallen zijn - heeft meer dan wij gedurfd. Het heeft met kwistige hand publieke werken van verkeer (zoogenaamde outillage économique) aangelegd, het heeft zijn steden verfraaid door reusachtige verbouwing van gansche wijken en aanleg van grootsche parken, het heeft publieke gebouwen gesticht, die in gansch Europa ternauwernood hun wederga vinden. De Belgische schuld in 1830 geen zesde part van de onze is daardoor (de schuld in zake de spoorwegen aangegaan, buiten rekening gelaten) aan de onze gelijk geworden. Maar men zal ook niet kunnen ontkennen, dat België van al die, volgens onze 
thans gangbare begrippen "onproductieve" uitgaven in hooge mate de vruchten plukt. Brussel en Antwerpen kunnen in één adem worden genoemd met de schoonste moderne steden. De publieke dienst is er overal behoorlijk ondergebracht. Paleizen, parken, bosschen en musea lokken den vreemdeling en strekken tot genot en ontwikkeling van de ingezetenen. Door geld in de zaak te steken - zij het ook hier en daar in het overdrevene en met de groote fout, dat er niet behoorlijk op al de bezittingen wordt afgeschreven in den vorm van voldoende amortisatie - heeft België zich tot de belangrijkste, de meest bekende van de kleine natiën gemaakt.

En wij? Onze steden zijn zeer schoon, ja, maar hoofdzakelijk als reliquien. In onze publieke gebouwen kunnen wij den vreemdeling die er komt uit nieuwsgierigheid of voor zaken, veelal niet dan met een zekeren schroom ontvangen. Onze ministeriën zijn voor een deel allerbedroevendst gehuisvest; niet zelden ten ongerieve van den dienst in een aantal gehuurde burgerwoningen verspreid over een gansche stadswijk, onze universiteiten zijn onvoldoende gehuisvest en onvoldoende geoutilleerd, de huisvesting van het hoofd van den Staat is niet veel meer dan het minimum dat mogelijk is. $\mathrm{Na}$ het Rijksmuseum .en het Station te Amsterdam heeft het Rijk bijna geen gebouw meer gesticht, dat ten sieraad strekt van de stad waar het staat. De bouw van het Vredespaleis, dat nog geen achtste deel zal kosten van hetgeen België voor zijn Paleis van Justitie uitgaf, is dientengevolge een verbazend evenement, zóózeer dat hij als het ware met aarzeling werd aangevat en uitgevoerd en dat evenement geschiedt met geld van een rijken Amerikaanschen particulier. Kortom wij durven geen geld in onze zaak te steken. Zelfs onze oude roem van voor niets vervaard te zijn, waar het publieke werken geldt, houden wij niet op. De Zuiderzee blijft, hoe vaak ook buitenlandśche tijdschriften hun lezers reeds met opgetogenheid hebben verhaald van de provincie, die wij bezig zijn op vredelievende wijze te veroveren, een zoutwaterplas, hinderlijk voor de omgeving; de Maas blijft tot schade van de eenige provincie, die de ziel van alle industrie in haar schoot bergt, een onbevaarhaar stroompje; het spoorwegverkeer 
met de vèr van het centrum gelegen provincien is onvoldoende door het ontbreken van dubbel spoor op hoofdlijnen.

Door dat alles exploiteeren wij duur en zien wij onze inkomsten niet in zoo snel tempo stijgen als onze buren. Ook voor een staat geldt, dat wie geen geld in zijn zaken durft steken in gelijke mate als zijn concurrenten, op den duur achterblijft en in het vergeetboek raakt.

Schrijver dezes is zich wel bewust, dat hij, voor zoover zijn invloed strekte, niet in de hand heeft gewerkt, dat er meer groote zaken desnoods met geleend geld werden aangepakt. Bij ons tegenwoordig systeem is echter de uitbreiding van de rubriek buitengewone uitgaven een hellend vlak, waarop men steeds verder glijdt, zonder te weten waar men blijft. Zoolang men niet goed boek houdt, dientengevolge eigenlijk niet goed weet wat men doet en veel aan het toeval overlaat, is het een gebiedende eisch van financieel beheer, dat de zeer voorzichtige kant gehouden worde. België's voorbeeld te volgen om voor vele zaken te leenen en geen andere afschrijving te hebben dan in den vorm van een zeer langzame aflossing van de leeningen, verdient gewis geen navolging; vroeger of later loopt het spaak.

lets anders wordt het echter, als men een economische boekhouding invoert, die gemakkelijke maakt te zorgen, dat men het Staatsvermogen op peil houdt. Men heeft zulks reeds gevoeld bij de geweren en het snelvuurgeschut; het heeft een vasteren vorm aangenomen in de voorstellen betreffende de veel gesmade fondsen voor de stelling van Amsterdam en voor de kustverdediging. Een streven om op die wijze ook andere zaken tot stand te brengen, waarvoor men niet op langen termijn leenen kan en die toch ook niet ten laste van den gewonen dienst kunnen worden gebracht, heeft zich geopenbaard. Maar men kan toch niet voor alles fondsjes maken; bij de inrichting van zulke fondsjes wordt daarenboven slechts op de toekomst, niet op 't verleden gelet. Wil men in die richting, dan flink aangevat en één fonds (of rekening) voor buitengewone werken gesticht, met behoorlijke regeling voor het overgangstijd perk.

De Bedrijvenwet is een stap in de goede richting, waar- 
mede ten minste bereikt wordt, dat de Staatsbedrijven hun vleugels kunnen uitslaan en niet langer hunne uitgaven beoordeeld zien, zonder verband met de inkomsten van heden en toekomst.

Doch men blijve daarbij niet staan, doch wage den sprong om, de boekhouding van het gansche Staatsfinanciewezen te sturen in de richting, van die, welke bij klein- en grootbedrijf zich sinds lang als de meest practische heeft uitgewezen, een richting die ook geheel in overeenstemming is met de moderne economische inzichten omtrent waarde en rente.

Een bezwaar, dat zeker in de eerste plaats tegen veranderingen als aangegeven zal worden gemaakt is, dat men het overzicht over de begrooting verliezen zal. $\mathrm{Zij}$, die aldus redeneeren, hebben zich blijkbaar nimmer rekenschap gegeven, hoe weinig het overzicht, dat wij nu hebben, beteekent. Met bloote totaalcijfers, waarin de meest ongelijksoortige grootheden als volkomen gelijkwaardig begrepen zijn, krijgt men van het Staatsiinanciewezen evenmin inzicht als van eenig ander. Wie er mede tevreden is, is te vergelijken met een winkelier, die den gang van zaken beoordeelt naar den inhoud der toonbanklade zonder op zijn overige bezittingen te letten. Natuurlijk zal bij een betere boekhouderij eenige meerdere inspanning gevraagd worden van dengene die van de financiën wenscht kennis te nemen, maar hij zal dan ook meer doen dan het lezen van weinig beteekenende cijfers. Niet eenvoud, die in werkelijkheid niets is dan duisternis, moet het doel zijn doch "publiciteit" volgens vaste regels, zoodat geheimzinnige knutselarij is uitgesloten. Uit de cijfers, welke de geheele volksvertegenwoordiging met een oogopslag moet kunnen beoordeelen moet alles geelimineerd worden wat ze onzuiver maakt. Het is voldoende als dit elimineeren van al wat een reëel en juist inzicht belemmert, volgens goede grondslagen geschiedt, vooreerst zooveel mogelijk volgens wettelijke regeling plaats heeft, voor welker handhaving de Rekenkamer kan zorgen en overigens wordt gecontroleerd door hen, die in de volksvertegenwoordiging in het bijzonder aan de financiën hunne aandacht wijden. De financieele kwesties, waarover de Kamer beslissingen 
heeft te nemen, moeten haar ten slotte als hoogst eenvoudige vraagpunten worden voorgelegd, waarover elkeen die een beetje gezond verstand heeft, zich gemakkelijk een oordeel kan vormen. Men zegge niet, dat men in dat geval te zeer gaat afhangen van de financieele specialiteiten. Men doet zulks ook nu, maar... ook die specialiteiten tasten thans in het duister. Hun eenige houvast bij hunne betoogen omtrent den toestand der zaak zijn... de toonbanklade en de lijst van crediteuren.

A. van Gijn. 